\title{
Discipline Development Of Civil State Employees In Improving Community Services
}

\author{
Hery Supriyanto ${ }^{1}$
}

\begin{abstract}
Civil servants as servants of the state and servants of the community in carrying out their duties to provide services to the community must be equitably distributed with the ability to carry out their duties in a professional and responsible manner, by obeying their obligations and avoiding prohibitions stipulated in statutory regulations and or official regulations. Based on the above facts, it is necessary to have a scientific study in a study with the title: Fostering Discipline of Civil Servants (PNS) in Improving Community Services Based on Government Regulation Number 53 of 2010 in Pemalang Regency.

The approach method used or used in this research is to use a sociological juridical approach (socio legal research). This research is a descriptive analysis research, that is, this research is a descriptive analysis research, which describes the existing situation more clearly, based on legal theory. Data analysis was carried out using qualitative analysis methods, namely an analysis carried out on the Discipline Development of Civil Servants in improving community services in Pemalang Regency. In Fostering Discipline for Civil Servants in Improving Community Service in Pemalang Regency, in general, Civil Servants as State Servants and Servants of the Community in carrying out their duties to provide services to the community must be disciplined, namely the existence of good Discipline Development for Civil Servants will create harmonious interactions, both between Civil Servants themselves and fellow bureaucratic officials as well as between employees and community members. Constraints faced Not exactly the promised time, Lack of quality of community services. in making Identity Cards (KTP) and Family Cards (KK), and for solutions to overcome Constraints / Obstacles are as follows: Implement services on time, Improve the quality of services to the community.
\end{abstract}

Keywords: Civil Servant Discipline, Service to Society

\section{Introduction}

Since the introduction of the post-reform regional autonomy policy, service quality and work productivity, the government bureaucracy needs to revitalize and reform its administrative system, which is popularly known as improving the utilization of the State apparatus. ${ }^{2}$ Likewise, since the implementation of Law Number 22 Year 1999 as amended by Law Number 32 Year 2004 concerning Regional Government, there have also been significant changes in the government system, from centralizing to decentralization.

Decentralization is the handover of governmental authority by the

\footnotetext{
1 Students of Master of Law, Faculty of Law, Universitas Islam Sultan Agung.

2Samodra Wibawa, 2006 , Reformasi Administrasi, Gaya Media, Yogyakarta,, p. 101
} 
Government to autonomous regions to regulate and administer government affairs in the system of the Unitary State of the Republic of Indonesia.

In line with these changes, there has also been a change in authority in the field of Personnel which is quite complex, in which Regional Civil Service Officers based on Government Regulation of the Republic of Indonesia Number 9 of 2003 concerning the Authority to Appoint, Transfer and Dismiss Civil Servants, have very vital authority, namely from starting from the appointment of employees, transfer of employees to dismissal of employees both structural / functional and non-structural.

As a tangible manifestation of the attitude of the state apparatus in carrying out their duties and functions as mandated by the intended Law Number 28 of 1999, among others is reflected in the implementation of Public Services. Therefore it is necessary to continue efforts to improve the performance of the apparatus in the delivery of public services.

In describing the mandate of the national development system and anticipating the demands of the community, it is necessary to build good governance which places a balance of roles between the public sector (government), the private sector and the community in an equal partnership in carrying out governance in order to fulfill basic needs. community life. ${ }^{3}$

From the government side, the state apparatus must be able to work professionally, be able to uphold the rule of law, be neutral, think decentralized, be transparent and have discipline. From the private side, entrepreneurs must be able to increase production, alleviate poverty and unemployment in order to realize a fair and equitable development system. From the community side, citizens must participate in supporting national and regional development as a reflection of a modern, civilized, educated and dedicated society for the nation and state.

Community service is a community right, which must be fulfilled by the Government. This right is a constitutional right as stated in the 1945 Constitution, which mandates that the State is obliged to serve every citizen and resident to fulfill their basic needs in order to improve the welfare of society. All public interests must be carried out by the Government as State Administrators, namely in various service sectors, especially those concerning the fulfillment of civil rights and basic needs of society.

In other words, all interests related to the life of the people must or need a service. In reality, at this time these rights have not been fully obtained by the community, for example the services that occur in community services, for example the length of the process for making Identity Cards (KTP) and Family Cards (KK), which is complicated and takes too long.

As a result of this phoneme, there is a tendency for injustice in service to the community, where people who are classified as poor will find it difficult to get services so that the rights of the people that should be served are in the process of managing or making Identity Cards (KTP) and Family Cards (KK) easily, fast, but complicated by services that are not optimal and clearly this is detrimental to the people who want to be served quickly.

Of the various problems faced in an effort to improve services to the community, especially services in making Identity Cards (KTP) and Family Cards (KK),

${ }^{3}$ Membangun Kepemerintahan Yang Baik, LAN-RI, 2008, Jakarta, p. 37 
Government Agencies, in providing services, basically reflect community satisfaction, so that the quality of human resources directly or Indirectly, Civil Servants are required to develop good work discipline skills, so that in carrying out these tasks, the Civil Servants themselves, as State servants and public servants, can be held accountable for their responsibility. The government has issued regulations with the aim that the implementation of the duties of its employees can run in accordance with the expectations of the community. And one of the ways to get this attention is the effort to foster discipline for civil servants. in providing services to the community ..

With regard to the foregoing, in making this thesis the writer is interested in taking the title: Fostering Civil Servant Discipline in improving community services based on Government Regulation Number 53 of 2010 in Pemalang Regency

\section{Research Methods}

The research approach method used in this research is juridical socio-legal research. Sociological juridical is a legal research that emphasizes primary data / field data. ${ }^{4}$

The specifications of this research include analytical descriptive, which describes the existing situation more clearly, in relation to the implementation of laws and government regulations, then analyzed to determine the Discipline Development of Civil Servants in improving community services in Pemalang Regency.

Sources of data used in this study can be divided into 2 (two), namely Primary Data and Secondary Data. Primary data is data obtained directly from the community or from the field (Field Research). This data is obtained through interviews / interviews, namely the method of collecting data by holding questions and answers which are carried out systematically and based on the research objectives. Secondary data is literature data in the form of primary legal materials and secondary legal materials.

From the research results obtained in writing and orally then analyzed descriptively qualitatively, namely by collecting data obtained from the research field by linking to law or literature related to Civil Service Development in improving community services in Pemalang Regency,

\section{Research Results and Discussion}

\subsection{Fostering Discipline of Civil Servants in Improving Community Service in Pemalang Regency}

The national objectives as stated in the preamble to the 1945 Constitution are to cover broad fields and many aspects which can only be achieved gradually through a series of national developments that are planned in a directed and realistic manner and are carried out seriously, honestly, efficiently. and effective.

The population of Pemalang Regency based on the state population data up to the first quarter of 2011, recorded a population growth rate of $1,402,898$ people, an increase of about 1,585 people from 2010. The number of female population is greater

\footnotetext{
${ }^{4}$ Ronny Hanitijo Soemitro, 1990, Metode Penelitian Hukum dan Jurimetri, Ghalia Indonesia, Jakarta, p. 122
} 
than the number of male population, indicated by gender, namely amounting to 699,480 men and 703,417 women, the difference is around 3,937 people. ${ }^{5}$

Along with the development of Pemalang Regency, the number of residents who have a need for services to the community, especially services for making Identity Cards (KTP) and Family Cards (KK) also increases. Based on the results of the research, the Service / Agency which is responsible for providing services to the community, Service for Issuance of Identity Cards (KTP), and Family Cards (KK), currently serves the community out of a total population of 1,402,898 people, has been served by 434,729 Issuance of Family Cards (KK), and as many as 833,011 Issuance of Identity Cards (KTP), to provide a clear picture of family card services in Pemalang Regency can be seen in the table. the following.

Table 1.

Data on the number of residents who have been served have a family card

\begin{tabular}{ccccc}
\hline NO & SUB-DISTRICT & The year 2010 & Year 2011 & Increase \\
\hline 1 & I hope & 17,516 & 17,516 & - \\
\hline 2 & Pulosari & 15,709 & 15,709 & - \\
\hline 3 & Belik & 29,137 & 29,137 & - \\
\hline 4 & Gathering time & 19,299 & 19,299 & - \\
\hline 5 & Bodeh & 16,531 & 16,531 & - \\
\hline 6 & Bantarbolang & 18,787 & 18,787 & - \\
\hline 7 & Randudongkal & 29,354 & 29,354 & - \\
\hline 8 & Pemalang & 50,878 & 63,356 & 12,478 \\
\hline 9 & garden & 46,407 & 46,407 & - \\
\hline 10 & Fight & 48,946 & 49,647 & 701 \\
\hline 11 & Ampelgading & 20,450 & 20,727 & 277 \\
\hline 12 & Comal & 20,500 & 20,738 & 238 \\
\hline 13 & Ulujami & 73,697 & 73,848 & 151 \\
\hline 14 & Warungpring & 13,673 & 13,673 & - \\
\hline & total & 420,884 & 434,729 & 13,845 \\
\hline
\end{tabular}

Data source: Disdukcatpil

Based on the table above, it can be seen that the total population in Pemalang Regency is 1,402,898 people, while only being served until the first quarter of 2011 is 434,729 family card (KK) issuances, so there are still around 968,169 family card issuances ( KK) who have not been able to be served, may be from an insufficient age, etc., and or are not yet married, they are still living with their parents.

\footnotetext{
${ }^{5}$ Results of interviews with Drs. Achmad Hidayat Head of Population Registration at Pemalang Regency Disdukcatpil.
} 
In addition to services to the community in the form of Family Card (KK) services, there are also services for making Identity Cards (KTP). The population in Pemalang Regency is 1,402,898 people, while only being served until the first Quarter of 2011 is 833,011 Issuance Identity Card (KTP), so that the number of people who have not been served is 569,887 , this is possible from the number of people who are not old enough or not yet mature. From the existing data, the Identity Card Making Service is as shown in table 4.2 .

Table 2

Data Of The Number Of Populations That Have Been Served Have Population Id Card

\begin{tabular}{ccccc}
\hline NO & SUB-DISTRICT & The year 2010 & Year 2011 & Increase \\
\hline 1 & I hope & 44,876 & 49,280 & 4,404 \\
\hline 2 & Pulosari & 57,006 & 57,006 & - \\
\hline 3 & Belik & 71,143 & 71,143 & - \\
\hline 4 & Gathering time & 42,259 & 39,892 & $(2,367)$ \\
\hline 5 & Bodeh & 30,306 & 30,144 & $(162)$ \\
\hline 6 & Bantarbolang & 66,505 & 41,686 & $(24,819)$ \\
\hline 7 & Randudongkal & 55,140 & 111,479 & 56,339 \\
\hline 8 & Pemalang & 108,212 & 137,364 & 29,152 \\
\hline 9 & garden & 55,394 & 47,691 & $(7,703)$ \\
\hline 10 & Fight & 57,193 & 63,731 & 6,538 \\
\hline 11 & Ampelgading & 37,378 & 37,731 & 353 \\
\hline 12 & Comal & 45,190 & 46,583 & 1,393 \\
\hline 13 & Ulujami & 73,917 & 74,277 & 360 \\
\hline 14 & Warungpring & 25,004 & 25,004 & - \\
\hline & total & 769,523 & 833,011 & 63,488 \\
\hline
\end{tabular}

Data source: Department of Population and Civil Registration, 2011

Based on the table above, it can be seen that the number of people served in the issuance of making Identity Cards (KTP) is more than those who are served by making family cards (KK). This shows that the number of people who have reached the age or adulthood who are required to have a Identity Card (KTP) has increased, and the people of Pemalang Regency have not all taken advantage of services to the community in making Identity Cards (KTP), so that when it is connected with the aims and objectives of It can be said that the implementation of Population Administration has not been fully achieved. In simple language it can be stated that the performance of the State Apparatus in this case providing services to the community has not yet achieved optimal goals.

According to Pemalang Regent Regulation Number 59 of 2008 concerning Guidelines for Implementation of Pemalang Regency Regional Regulation Number 8 of 2008 concerning Administration of Population, the administrative costs in managing Identity Cards (KTP) and Family Cards (KK) are stipulated to be free of charge. However, this Regional Regulation is not implemented properly by officers, in this case Civil Servants who are assigned to KTP and Family Card Services, in this case it is not their service / agency. The conditions mentioned above are generally triggered by 
ineffective administrative services, especially in terms of administration of records, filing systems, organizing letters and the effective use of administrative books in the village and sub-district.

Basically, the document administration service process has undergone significant development. Even the service mechanism starting at the lowest level of governmental organizations until the publication of a document has tried to display work efficiency and effectiveness by empowering all elements involved in serving the community. In providing good service quality is a system of openness of service officers in providing satisfaction to the community / customers. Openness in the service process can be seen from the officers providing information openly whether requested or not. Therefore, the quality of human resources in this case is very important.

\subsection{Constraints in the Implementation of Discipline Development for Civil Servants in Pemalang Regency}

The implementation of Discipline Development for Civil Servants in Improving Community Services based on Government Regulation No. 53/2010 in Pemalang District has not gone as expected. There are obstacles encountered in the process of issuing Identity Cards (KTP) and Family Cards (KK), including:

1) Not exactly the promised time

One of the most important factors in making family cards (KK) and / or identity cards (KTP) is the readiness of officers to accept changes in transparency, as well as in the mentality of officers in their work.

The National Identity Card (KTP) and Family Card Program are Government Programs that must be implemented by every Indonesian citizen. Officers who feel underestimated by the demands of citizens who want to be served quickly.

2) Lack of quality community service.

Public services to citizens in general have not been fully implemented by Civil Servants / Officers. This low public service is felt to be detrimental to the interests of the community. People as consumers really need fast and excellent service.

In fact, the Civil Servants in charge of serving the community are not / are not in accordance with the expectations of the community. The service system does not fully reflect the openness system, there are still rules and regulations that are kept secret for the benefit of the community, there are still services between one community and another. Officers who carry out Identity Card Making Services (KTP) and Family Cards (KK) tend to provide better / faster service to community members who will reward something outside the existing provisions. This condition will reduce the image and dignity of Civil Servants who are trusted to provide services to the community.

Based on the aforementioned provisions, it can be explained that the existence of Civil Servants who are assigned to provide services to the community is a form of indiscipline of Civil Servants (PNS) based on Government Regulation Number 53 of 2010. 


\subsection{The efforts made to overcome these obstacles are as follows:}

\section{1) Carry out services on time.}

Based on the results of the research, one of the obstacles encountered was in the uncertain time promised, so what needs to be done is to provide solutions to Civil Servants who are tasked with providing services to the community in making / issuing Identity Cards and Family Cards (KK), to work on an independent basis. professional, transparent, implementing rules and regulations and regulations. In managerial terms, in our opinion, in this era of openness, customer / service user satisfaction must be prioritized because in effect, they are the ones who pay the employees who are assigned to provide services to the community.

\section{2) Improve the quality of service to the community.}

In the context of facing the Globalization Era, Civil Servants as State servants and public servants are required to have the ability and sensitivity to the situations and conditions that occur in their duties. The rapid flow of information makes the boundaries between districts and other districts seem to no longer exist.

\section{Closing}

\subsection{Conclusion}

The results of research and discussion on the Development of Civil Servant Discipline in Improving Community Services based on Government Regulation Number 53 of 2010 in Pemalang Regency can be concluded:

1) Civil Servant Discipline Development (PNS) in Community Service Improvement based on Government Regulation No. 53/2010 in Pemalang Regency has generally been implemented in accordance with the conditions and developments. The disciplinary fostering of Civil Servants aims to shape the character of Civil Servants who carry out their duties not to deviate from the prevailing rules and regulations. As state servants and public servants so that they can serve professionally and transparently.

2) The problems faced in the Civil Servant Discipline Development (PNS) can be described as obstacles, including the exact time promised in providing services to the community. The number of promises made by Civil Servants who carry out services for making Family Cards (KK) and / or Identity Cards (KTP) that shouldn't have to be made, because promises are the hope of the community, and in a procedural manner the rules and regulations are clear set it up. And the lack of quality of service to society, where the attitude of civil servants who serve the community, is not in accordance with the expectations of society.

In the framework of efforts to overcome these obstacles, among others, are: meeting the promised time, namely Civil Servants (PNS) to provide services to the community, especially in making Identity Cards (KTP) and Family Cards (KK) services, can be carried out on time, do not stall for time, do not have to give promises because promises are debts, and those who deny promises in the hereafter will be asked, and also improve the quality of community services, where services to the community through an information service must be on time, accurate with a attentive and 
friendly approach to improving service quality. Improving the quality of service is very important in order to create customer satisfaction.

\subsection{Suggestion}

Given that the implementation of Discipline Development for Civil Servants in Improving Service to the community still faces several obstacles, it is necessary for the related Service / Agency to find the most appropriate solution so that the implementation of services to the community can run well. One solution that can be carried out by Civil Servants who are tasked with providing services to the community, especially services in the manufacture and issuance of Identity Cards (KTP) and Family Cards (KK), are:

1) Improve discipline both in going to work and in carrying out their duties, so that Civil Servants (PNS) as servants of the State and servants of the community can provide excellent service.

2) Civil Servants as Servants to the community are not the opposite of Civil Servants to be served, not serving with power.

\section{Bibliography}

[1] Ateng Syafruddin, 1987, Pengaturan koordinasi pemerintah di daerah Tarsito, Bandung

[2] Dann Sugandha, 1986, Organisasi dan Sistem Pemerintahan Negara Republik Indonesia Serta Pemerintahan di Daerah, Sinar Baru, Bandung,

[3] Djauhari, 2008, Politik Hukum Negara Kesejahteraan Indonesia, Unisulla Press, Semarang

[4] Erwan Agus Purwanto dan Wahyudi Kumorotomo, 2009, Biroklrasi Publik dalam Sistem Politik Semi Parlemnter, Gava Media, Yogyakarta,

[5] Evi Hartanti, 2005 Tindak Pidana Korupsi, Sinar Grafika, Jakarta

[6] Fitriyah, 1995, Pemerintahan Yang Bersih, dalam Forum, majalah pengembangan Ilmu-ilmu Sosial, Fisip Press, Semarang

[7] Moh. Mahfud, 1988, Hukum Kepegawaian Indonesia, Liberty, Jogyakarta

[8] Miftah Thoha, 1994, Perilaku Organisasi Konsep Dasar dan Aplikasinya, Raja Grafindo Persada, Jakarta,

[9] Manulang, 1962, Dasar-dasar Manajemen BAPPIT, Medan,

[10] Misdyanti dan RG Karta Sapeotra, 1993, Fungsi pemerintah daeerah dalam pembuatan peraturan daerah, Bumi aksara, Jakarta

[11] Moeljarto Tjokrowinoto dkk, Pustaka Pelajar Offset bekerjasama dengan Pusat Studi Kewilayahan UMM

[12] Nuraida Mukhsen, 2002, Reformasi Manajemen Kepegawaian Untuk Meningkatkan Kapasitas Aparatur, Kementerian PAN, Jakarta,

[13] Prastisto Prawoto Soediro Adalah, 1983 Pegawai Negeri Sipil, Pradya Paramita Jakarta

[14] Samodra Wibawa, 2006, Reformasi Administrasi, Gava Media, Yogyakarta,

[15] Sianipar, 2000, Manajemen Pelayanan Masyarakat, LAN-RI, Jakarta,

[16] Winardi, 1974 Asas-asas Manajemen, Alumni, Jakarta 